\title{
ПОНЯТИЕ И СУЩНОСТЬ ПРОИЗВОДСТВА ПО ЖАЛОБАМ В ДЕЯТЕЛЬНОСТИ ТАМОЖЕННЫХ ОРГАНОВ
}

A дминистративная и правовая деятельность таможенных органов - это государственная, властная, подзаконная, исполнительная и распорядительная деятельность, направленная на организацию и практическое решение задач по выполнению функций таможенных органов в сфере организации и функционирования таможенной системы, обеспечения экономической безопасности государства и осуществляемая в административно-правовых формах с использованием административно-правовых методов.

Административные процедуры, реализуемые в деятельности таможенных органов, должны защищать граждан, юридических лиц и индивидуальных предпринимателей, но эти процедуры далеко не всегда достигают цели. В связи с этим в ходе реализации таможенных процедур возникает необходимость в защите прав и законных интересов граждан, юридических лиц, а также индивидуальных предпринимателей.

Административные правоотношения в ходе реализации права жалобы порождаются не только позитивными действиями, но и действиями, которые носят противоправный характер. В этой связи граждане, юридические лица, а также индивидуальные предприниматели вынуждены прибегать к восстановлению или защите своих нарушенных прав.

Законодательством предусмотрены следующие фрормы защиты нарушенных прав:

- способ судебный защиты;

- способ административный защиты;

- самозащита.

Решения, действия (бездействие) таможенных органов или их должностных лиц могут быть обжалованы в таможенные органы и (или) в суд, арбитражный суд. Подача жалобы на решение, действие (бездействие) таможенного органа или его должностного лица в таможенные органы не исключает возможности одновременной или последующей подачи жалобы аналогичного содержания в суд, арбитражный суд. Жалоба на решение, действие (бездействие) таможенного органа или его должностного лица, поданная в таможенные органы и в суд, арбитражный суд, рассматривается судом, арбитражным судом. Порядок подачи, порядок рассмотрения и порядок разрешения жалоб, направляемых в суды и арбитражные суды, определяются законодательством РФ о гражданском судопроизводстве и судопроизводстве в арбитражных судах (ст. 36, 37 гл.3 Ф3 от 27 ноября 2012 г. № 311-Ф3, далее Федеральный закон) ${ }^{1}$.

Жалоба на решение, действие (бездействие) таможенного органа или его должностного лица может быть подана в течение трех месяцев:

- $\quad$ со дня, когда лицу стало известно или должно было стать известно о нарушении его прав, свобод или законных интересов, создании препятствий к их реализации либо незаконном возложении на него какой-либо обязанности;

- co дня истечения установленного срока для принятия таможенным органом или его должностным лицом решения или совершения действия, установленного актом таможенного законодательства Таможенного союза, актом законодательства РФ о таможенном деле либо иным правовым актом РФ в области таможенного дела (ст. 40 Федерального закона).

Форма и содержание жалобы в административно-таможенном процессе должны содержать следующую информацию:

Жалоба подается в произвольной письменной форме, в ней указывается:

- кем подается жалоба (фамилия, имя, отчество фризического лица, наименование юридического лица, его место жительства или нахождения);

- реквизиты обжалуемого постановления (наименование таможенного органа, должностным лицом которого оно вынесено, номер дела об административном правонарушении, дата вынесения, лицо, в отношении которого вынесено);

- причины несогласия с вынесенным постановлением, а также оригиналы либо надлежащим образом заверенные копии документов, которыми могут быть подтверждены изложенные в жалобе обстоятельства;

\footnotetext{
${ }^{1}$ См.: СЗ РФ. - 2010. - № 48. - Ст. 6252.
} 


\section{Полицейская деятельность $2 \cdot 2013$}

- требования лица, обращающегося с жалобой (об изменении постановления; об отмене постановления и о прекращении производства по делу; об отмене постановления и о возвращении дела на новое рассмотрение, об отмене постановления и о направлении дела на рассмотрение по подведомственности);

- почтовый адрес, номер телефрона, фракса (если имеются), по которому лицо, обратившееся с жалобой, может быть извещено о дате, месте и времени рассмотрения жалобы; - имеющиеся у лица ходатайства;

- перечень прилагаемых к жалобе документов;

- иные сведения, которые лицо считает необходимым для рассмотрения жалобы.

Жалоба подписывается подавшим ее лицом. В жалобе, поданной юридическим лицом, указывается должностное положение лица, которым она подписана. От имени юридического лица жалоба может быть подписана генеральным директором (директором) либо иным лицом, имеющим полномочия на подписание жалобы от имени юридического лица.

Жалоба на решение, действие (бездействие) таможенного органа или его должностного лица подается в письменной форме и должна быть подписана лицом, обратившимся с жалобой. Жалоба на решение, действие (бездействие) таможенного органа или его должностного лица должна содержать:

- наименование таможенного органа или должность, фрамилию, имя и отчество должностного лица таможенного органа (если они известны), решение, действие (бездействие) которых обжалуются;

- фрамилию, имя, отчество или наименование лица, подающего жалобу, его место жительства или местонахождение;

- существо обжалуемого решения, действия (бездействия).

Заявитель может не представлять документы, которыми подтверждаются обстоятельства, указанные в этой жалобе. Если представление таких документов имеет существенное значение для рассмотрения указанной жалобы и эти документы отсутствуют в таможенном органе, решение, действие (бездействие) которого или должностного лица которого обжалуются, таможенный орган, рассматривающий указанную жалобу, вправе запросить их у лица, ее подавшего. В этом случае срок рассмотрения жалобы на решение, действие (бездействие) таможенного органа или его долж- ностного лица приостанавливается до представления лицом запрошенных таможенным органом документов, но не более чем на три месяца. В случае непредставления лицом запрошенных таможенным органом документов решение по указанной жалобе принимается без учета доводов, в подтверждение которых не были представлены документы (ст. 42 Федерального закона).

Таможенные органы не рассматриваются жалобы по существу в следующих случаях:

- если не соблюдены установленные сроки обжалования и лицо не обратилось с заявлением о восстановлении пропущенного срока для обжалования либо заявление о восстановлении пропущенного срока для обжалования отклонено;

- если не соблюдены требования, установленные ч. 1 и 2 ст. 42 настоящего Федерального закона;

- если лицо уже обратилось с жалобой аналогичного содержания в суд и такая жалоба принята судом, арбитражным судом к рассмотрению либо по ней вынесено решение;

- если предметом указанной жалобы являются решение, действие (бездействие) органа, не являющегося таможенным органом, или должностного лица органа, не являющегося таможенным органом;

- если жалоба подана лицом, полномочия которого не подтверждены в порядке, установленном ст. 39 Федерального закона;

- если жалоба подана лицом, права, свободы или законные интересы которого обжалуемым решением, действием (бездействием) не были затронуты;

- если предметом жалобы является акт (документ) таможенного органа или его должностного лица, не являющийся решением в области таможенного дела;

- если имеется решение, принятое в соответствии со ст. 48 Федерального закона этим же таможенным органом в отношении того же заявителя и о том же предмете жалобы;

- если отсутствует предмет обжалования, то есть фракт принятия решения таможенным органом либо совершения им действия (бездействия) не подтвердился.

Федеральный закон от 2 мая 2006 г. «О порядке рассмотрения обращений граждан РФ»², где гражданин в своем письменном обращении

\footnotetext{
2 См.: СЗ РФ. - 2006. - № 19. - Ст. 2060.
} 
в обязательном порядке указывает либо наименование государственного органа или органа местного самоуправления, в которые направляет письменное обращение, либо фамилию, имя, отчество соответствующего должностного лица, либо должность соответствующего лица, а также свои фрамилию, имя, отчество, почтовый или электронный адрес, по которому должны быть направлены ответ, уведомление о переадресации обращения, излагает суть предложения, заявления или жалобы, ставит личную подпись и дату. В случае необходимости в подтверждение своих доводов гражданин прилагает к письменному обращению документы и материалы либо их копии. Данная информация должна содержаться и в жалобе, которая адресуется должностным лицам таможенной службы.

Право жалобы играет важную роль в соблюдении действующего законодательства, так как, с одной стороны, стоит на защите прав граждан и юридических лиц, с другой - помогает устранить ошибки и нарушения действующего законодательства, допускаемые должностными лицами таможенных органов.

Правовую основу института права жалобы, в деятельности таможенных органов в настоящее время составляют специальные нормативные правовые акты: Таможенных кодекс Таможенного союза, Кодекс РФ об административных правонарушениях, Федеральный закон от 27 ноября 2010 г. «О таможенном регулировании в Российской Федерации», Федеральный закон от 2 мая 2006 г. «О порядке рассмотрения обращений граждан РФ», приказ ФТС России от 10 сентября 2009 г. № 1660 «Об утверждении Административного регламента ФТС России по исполнению государственной функции организации приема граждан, обеспечения своевременного и полного рассмотрения обращений граждан, принятия по ним решений и направления ответов заявителям в установленном законодательством Российской Федерации срок» ${ }^{3}$.

Жалоба на решение, действие (бездействие) таможенного органа подается в вышестоящий таможенный орган.

Жалоба на решение, действие (бездействие) должностного лица таможенного органа подается в таможенный орган, в котором проходит службу (замещает государственную должность) это лицо,

\footnotetext{
3 См.: Бюллетень нормативных актов федеральных органов исполнительной власти. - 2010. - № 9.
}

а на решение, действие (бездействие) начальника таможенного органа - в вышестоящий таможенный орган. Жалоба на решение, действие (бездействие) таможенного органа или его должностного лица может быть подана как непосредственно в вышестоящий таможенный орган, так и через таможенный орган, решение, действие (бездействие) которого или начальника которого обжалуется. Таможенный орган, на решение, действие (бездействие) которого или начальника которого подана жалоба, направляет ее в вышестоящий таможенный орган вместе с подтверждающими материалами в пятидневный срок со дня ее поступления. В случаях, когда таможенный орган, получивший жалобу на решение, действие (бездействие) таможенного органа или его должностного лица, не правомочен ее рассматривать, он обязан направить ее в трехдневный срок в таможенный орган, который должен ее рассматривать в соответствии с настоящей статьей, с уведомлением в письменной форме лица, подавшего жалобу. Жалоба на решение, действие (бездействие) федеральной службы, уполномоченной в области таможенного дела, подается в эту службу4.

Если административно-правовые средства защиты прав физических и юридических лиц не дали положительного результата, то, возможно, использовать судебные средства защиты. Судебный контроль в исследуемой ссрере может проявить себя в двух фрормах: во-первых, судебный контроль может осуществляться за деятельностью должностных лиц таможенных органов; вовторых, судебный контроль может осуществляться за законностью административных решений принимаемых должностными лицами таможенных органов.

В завершении рассмотрения административных правоотношений, складывающихся в связи с защитой прав граждан, юридических лиц и индивидуальных предпринимателей необходимо сказать, что без данного элемента эффрективная работа таможенных органов была бы невозможна. В свою очередь совершенствование правоприменительной деятельности в сфрере реализации административно-таможенных процедур будет способствовать укреплению законности и правопорядка в таможенном деле РФ.

\footnotetext{
${ }^{4}$ См.: Звягин М.М., Сафронов В.А., Куракин А.В. Таможенныежалобы: понятие, сущность, производство. Часть первая// Право и политика. - 2010. - № 3. - С. 403.
} 


\section{Полицейская деятельность $2 \cdot 2013$}

\section{Библиографический список:}

1. Алистратов Ю.Н. Право петиций в Российской Федерации. - М., 1997.

2. Буденко Н.И., Ерилин Н.П. Организация работы дежурных частей и участковых инспекторов милиции с заявлениями, предложениями и жалобами граждан. - М., 1990.

3. Бутылин В.Н. Рассмотрение жалоб граждан на действия работников органов внутренних дел ущемляющих права и законные интересы граждан. - М., 1992.

4. Волков С.С. Лексика русских челобитных. - Л., 1974.

5. Звягин М.М., Сафронов В.А., Куракин А.В. Таможенные жалобы: понятие, сущность, производство. Часть первая // Право и политика. — 2010. - № 3.

6. Габричидзе Б.Н., Зобов В.Е. Таможенная служба в Российской Федерации. - М., 1993.

7. Габричидзе Б.Н., Суслов Н.А. Таможенные органы Российской Федерации: правовой статус и пути его совершенствования // Государство и право. — 1995. — № 3.

\section{References (transliteration):}

1. Alistratov Yu.N. Pravo petitsiy v Rossiyskoy Federatsii. - M., 1997.

2. Budenko N.I., Erilin N.P. Organizatsiya raboty dezhurnykh chastey i uchastkovykh inspektorov militsii s zayavleniyami, predlozheniyami i zhalobami grazhdan. - M., 1990.

3. Butylin V.N. Rassmotrenie zhalob grazhdan na deystviya rabotnikov organov vnutrennikh del ushchemlyayushchikh prava i zakonnye interesy grazhdan. - M., 1992.

4. Volkov S.S. Leksika russkikh chelobitnykh. — L., 1974.

5. Zvyagin M.M., Safronov V.A., Kurakin A.V. Tamozhennye zhaloby: ponyatie, sushchnost', proizvodstvo. Chast' pervaya // Pravo i politika. — 2010. — № 3.

6. Gabrichidze B.N., Zobov V.E. Tamozhennaya sluzhba v Rossiyskoy Federatsii. - M., 1993.

7. Gabrichidze B.N., Suslov N.A. Tamozhennye organy Rossiyskoy Federatsii: pravovoy status i puti ego sovershenstvovaniya // Gosudarstvo i pravo. — 1995. - № 3. 